\title{
HUBUNGAN DUKUNGAN SOSIAL SUAMI DENGAN EFIKASI DIRI ISTRI DALAM MENJALANI MASA MENOPAUSE
}

\author{
Fayakun Nur Rohmah" ${ }^{1^{*}}$, Ismarwati $^{2}$
}

\begin{abstract}
${ }^{12}$ Program Studi Kebidanan jenjang DIII, Universitas 'Aisyiyah Yogyakarta. Jalan Ringroad Barat No.63, Mlangi, Nogotirto, Gamping, Sleman, Yogyakarta, e-mail : fayakun.nurrohmah@gmail.com
\end{abstract}

\begin{abstract}
Background :Yogyakarta has an olderly population structure (pre-elderly and elderly) women among most other provinces in Indonesia that means the majority number of women is in menopause. Every woman has different response and complaints that occurred before and after menopause. Good self-efficacy will help women to face the complaints toward menopause.

Objectives : This research aimed to analyze the correlation between husband's support and woman's selfefficacy towards menopause from a female perspective.

Methods : This research was a correlational study with cross sectional approach. The sample technique of this study was accidental sampling technique, with the number of 32 women in menopause as the samples. Data were analyzed with Chi-square.

Result :As the result, $p$-value was 0.378 ( $p>0.05)$.

Conclusion : There were no correlation between husband's support and women's self efficacy towards menopause.
\end{abstract}

Keyword : Menopause, self efficacy, husband support

\section{PENDAHULUAN}

Daerah Istimewa Yogyakarta memiliki struktur penduduk tua (pra lansia dan lansia perempuan paling banyak di antara propinsi lainnya di Indonesia, yaitu sebesar 33,1\%. Perempuan dalam usia pra lansia dan lansia merupakan usia di mana perempuan mengalami menopause. ${ }^{1}$

Survei di Jepang mengungkapkan bahwa faktor perubahan hormon khususnya penurunan estrogen dan didukung oleh faktor psikologi dan sosial memengaruhi terjadinya gejala atau keluhan pada perempuan klimakterium yang dapat mengakibatkan sindrom menopause. ${ }^{2}$

Sebagian perempuan menganggap masa tua sebagai masa yang menakutkan. Kekhawatiran ini berawal dari pemikiran bahwa dirinya akan menjadi tidak sehat, tidak bugar, dan tidak cantik lagi ketika masa menopause tersebut datang. Perempuan yang mengalami kecemasan umumnya disebabkan karena kurangnya informasi yang benar, sehingga yang dibayangkan adalah efek negatif yang akan dialaminya setelah memasuki masa menopause. Keadaan ini dikhawatirkan akan memengaruhi hubungannya dengan suami maupun lingkungan sosialnya. ${ }^{3}$

Respon seorang perempuan terhadap menopause berbeda-beda, dipengaruhi oleh banyak faktor. Keadaan sosial ekonomi 
seseorang akan memengaruhi faktor fisik, kesehatan, dan pendidikan. Apabila faktorfaktor tersebut cukup baik, akan mengurangi beban fisiologis dan psikologi. ${ }^{4}$ Keadaan tersebut akan memengaruhi efikasi diri pada perempuan menopause. Efikasi merupakan penilaian individu terhadap kemampuan dirinya untuk melakukan suatu tugas atau kegiatan. Faktor eksternal yang dapat berpengaruh terhadap efikasi diri adalah dukungan keluarga khususnya suami.

Dukungan dalam keluarga merupakan salah satu kekuatan, dukungan suami terhadap istri biasanya berpengaruh sangat kuat, karena suami istri merupakan sebuah sinergi. Keluarga merupakan sumber dukungan sosial bagi anggota keluarga lainnya, dukungan tersebut sangat diperlukan setiap individu dalam siklus kehidupannya. Dukungan sosial akan sangat dibutuhkan ketika seseorang sedang menghadapi masalah atau kesakitan, di sinilah peran anggota keluarga diperlukan untuk menjalaninya. $^{5}$ Dengan demikian peran suami menjadi hal penting yang berhubungan dengan efikasi diri perempuan dalam menjalani masa menopause.

\section{BAHAN DAN CARA PENELITIAN}

Jenis penelitian yang digunakan adalah survei analitik dengan pendekatan cross sectional. Penelitian ini bermaksud menganalisis hubungan dukungan suami dengan efikasi diri istri yang menghadapi menopause dari perspektif perempuan.
Populasi penelitian ini adalah seluruh perempuan menopause yang mengikuti posyandu lansia di kelurahan Baturetno, kecamatan Banguntapan. Sampel diambil menggunakan accidental sampling, dengan cara mengambil semua perempuan menopause yang hadir pada saat posyandu lansia sejumlah 32 orang pada bulan Februari 2015.

Pengumpulan data pada penelitian ini menggunakan kuesioner tertutup sejumlah 24 butir pada kuisioner dengan pilihan jawaban skala likert yaitu selalu, kadang, dan tidak pernah. Data dianalisis dengan menggunakan chi-square.

\section{HASIL DAN PEMBAHASAN}

Karakteristik responden

Tabel 1. Karakteristik Umur Responden

\begin{tabular}{ccc}
\hline Usia & $\mathbf{f}$ & $\%$ \\
\hline $45-50$ & 4 & 13 \\
$51-55$ & 9 & 28 \\
$56-60$ & 9 & 28 \\
$61-65$ & 7 & 22 \\
$66-70$ & 1 & 3 \\
$71-75$ & 2 & 6 \\
\hline Total & 32 & 100 \\
\hline
\end{tabular}

Mayoritas responden berusia 51-60 tahun yaitu masing-masing kelompok umur 51-55 tahun sebanyak 9 responden (28\%) dan 56-60 tahun sebanyak 9 responden (28\%), sedangkan minoritas responden berusia 66-77 tahun.

Frekuensi tingkat pendidikan terbanyak pada responden adalah berpendidikan SD yaitu sebanyak 11 responden (34\%) dan sebanyak 1 responden (3\%) responden tidak sekolah. 
Tabel 2. Karakteristik Tingkat Pendidikan

\begin{tabular}{lcc}
\multicolumn{3}{c}{ Responden } \\
\hline \multicolumn{1}{c}{ Tk. Pendidikan } & $\mathbf{f}$ & $\%$ \\
\hline Tidak sekolah & 1 & 3 \\
SD & 11 & 34 \\
SMP & 8 & 25 \\
SMA & 7 & 22 \\
PT & 5 & 16 \\
\hline Total & 32 & 100 \\
\hline
\end{tabular}

Tabel 3. Karakteristik Status Pekerjaan Responden

\begin{tabular}{lcc}
\hline Status Pekerjaan & f & $\%$ \\
\hline Bekerja & 14 & 44 \\
Tidak Bekerja & 18 & 56 \\
\hline Total & 32 & 100 \\
\hline
\end{tabular}

Mayoritas responden sudah tidak bekerja sebanyak 18 responden ( 56\%).

Tabel 4. Karakteristik Lama Menopause Responden

\begin{tabular}{lcc}
\hline Status Pekerjaan & $\mathbf{f}$ & $\%$ \\
\hline $0-5$ & 10 & 31 \\
$6-10$ & 11 & 34 \\
$11-15$ & 8 & 25 \\
$16-20$ & 1 & 3 \\
$21-25$ & 2 & 7 \\
\hline Total & 32 & 100 \\
\hline
\end{tabular}

Sebanyak 11 responden (34\%) sudah menopause selama 6-10 tahun dan sebanyak 1 responden (3\%) di antaranya sudah lebih dari 16 tahun.

Tabel 5. Distribusi frekuensi dukungan suami

\begin{tabular}{lcc}
\hline Status Pekerjaan & $\mathbf{f}$ & $\%$ \\
\hline Kuat & 24 & 75 \\
Lemah & 8 & 25 \\
\hline Total & 32 & 100 \\
\hline
\end{tabular}

Tabel 6. Distribusi frekuensi efikasi diri

\begin{tabular}{lcc}
\hline Status Pekerjaan & $\mathbf{f}$ & $\%$ \\
\hline Baik & 24 & 75 \\
Kurang baik & 8 & 25 \\
\hline Total & 32 & 100 \\
\hline
\end{tabular}

Tabel 7. hubungan dukungan suami dengan efikasi diri

\begin{tabular}{lccccc}
\cline { 2 - 5 } Efikasi & \multicolumn{2}{c}{ Baik } & \multicolumn{2}{c}{$\begin{array}{c}\text { Kurang } \\
\text { baik }\end{array}$} & $\begin{array}{c}\boldsymbol{\rho} \\
\text { value }\end{array}$ \\
Dukungan & $\mathbf{f}$ & $\%$ & $\mathbf{f}$ & $\%$ & \\
\hline Kuat & 19 & 79,2 & 5 & 62,5 & 0,378 \\
Lemah & 5 & 20,8 & 3 & 37,5 & \\
\hline Total & 24 & 100 & 8 & 100 & \\
\hline
\end{tabular}

Hasil uji statistik menggunakan chisquare diperoleh nilai Sig (2-tiled) atau $\rho$ value sebesar 0,378 yaitu $\rho$ value $>0,05$ sehingga Ho diterima dan $\mathrm{Ha}$ ditolak berarti tidak ada hubungan antara dukungan suami dengan efikasi diri pada perempuan menopause.

Menurut Bandura (1997) Efikasi diri adalah keyakinan seorang individu mengenai kemampuannya dalam mengorganisasi dan menyelesaikan suatu tugas yang diperlukan untuk mencapai hasil tertentu. Efikasi diri yakni keyakinan bahwa seseorang bisa menguasai situasi dan mendapatkan hasil positif. Efikasi diri berpengaruh besar terhadap perilaku.

Karakteristik lama menopause dan usia pada perempuan diasumsikan memberikan andil dalam sumber efikasi ini, perempuan yang lebih lama mengalami menopause sudah memahami kondisi dirinya sehingga dapat beradaptasi dan menjadi kekuatan untuk memiliki efikasi diri yang baik. Sebanyak 34\% responden sudah mengalami menopause selama 6-10 tahun.

Sebanyak 56\% responden sudah tidak bekerja. karakteristik status pekerjaan perempuan menopause dapat menjadi 
sumber persuasi sosial untuk memperkuat atau memperlemah efikasi diri pada perempuan menopause. Perempuan yang bekerja mempunyai kecenderungan untuk lebih banyak berinteraksi dengan lingkungan, dan dapat mengaktualisasikan dirinya. Sehingga dari interaksi tersebut dapat terjadi berbagai informasi, dan permasalahan serta pengalaman menghadapi masalah. ${ }^{8}$

Persuasi verbal merupakan informasi tentang kemampuan yang disampaikan secara verbal oleh seseorang yang berpengaruh, biasanya digunakan untuk meyakinkan seseorang bahwa seseorang mampu melakukan suatu tugas. Dorongan semangat yang diberikan kepada seseorang yang berpotensi dan terbuka menerima informasi meningkatkan efikasi dirinya. Semakin percaya orang kepada kemampuan pemberi informasi maka akan semakin kuat keyakinan untuk mengubah efikasi diri. Apabila penilaian diri lebih dipercaya daripada penilaian orang lain maka keyakinan terhadap kemampuan yang dimiliki sulit digoyahkan. $^{9}$

Bagi perempuan yang memiliki pekerjaan atau kegiatan yang dipilih dan disukainya akan memandang dan bersikap positif terhadap menopause. Mereka tidak mudah terserang cemas dan depresi. Cara berpikir mereka tidak sempit, dapat bertukar pikiran dengan teman kerja, lebih santai dan produktif, sehingga diasumsikan akan merasa lebih bahagia apalagi ada rasa aman secara finansial sehingga meningkatkan kepercayaan diri terhadap kemampuannya. ${ }^{10}$

Perempuan menopause yang memiliki kegiatan seperti bekerja dan berorganisasi umumnya lebih memiliki harga diri yang lebih baik. Perempuan menopause yang memiliki kesempatan yang lebih besar dalam berhubungan sosial dengan orang lain, dan lebih mudah berbagi solusi untuk menyelesaikan masalahnya dalam menghadapi perubahan menopause yang terjadi dengan rekan kerja atau orang di sekitarnya untuk menangani masalah menopause. Hal tersebut yang membantu wanita menangani peran sekaligus permasalahan dalam hidupnya. $^{7}$

Keaktifan mengikuti kegiatan atau berorganisasi di lingkungan terutama sesama menopause seperti posyandu lansia, arisan, pengajian, dan kegiatan sosial lainnya perempuan menopause akan dengan mudah berbagi dan mencari model yang baik untuk memotivasi dirinya meningkatkan efikasi diri. Sejalan dengan teori Bandura (1997) bahwa sumber lain yang menguatkan efikasi diri. Sumber ini diperoleh melalui model sosial. Apabila seorang melihat suatu kejadian, kemudian ia merasakannya sebagai kejadian yang dialami sendiri maka hal ini akan dapat memengaruhi perkembangan efikasi dirinya. Efikasi diri akan meningkat ketika mengamati keberhasilan orang lain yang dijadikan model dengan kemampuan yang kira-kira sama dengan kemampuan dirinya. Dampak dari modeling terhadap efikasi diri sangat dipengaruhi oleh kemiripan individu terhadap 
model. ${ }^{9}$

Model yang berperan sebagai perantara dalam proses penghayatan ini adalah dapat diamati dalam kehidupan sehari-hari maupun di televisi dan media visual lainnya, dengan menghayati kejadian yang seolah-oleh dialami, dengan bersosialisasi pada berbagai kegiatan maka perempuan akan dapat mencari model. ${ }^{9}$

Tingkat pendidikan perempuan menopause juga menjadi sumber pengembangan efikasi diri karena terkait dengan kepercayaan diri. Sebanyak 34\% responden memiliki tingkat pendidikan SD. Hasil penelitian Candra dkk. (2015) menunjukkan perempuan menopause yang memiliki tingkat pendidikan tinggi akan memiliki kepercayaan diri yang tinggi. Seseorang yang memperoleh pengalaman pendidikan dapat dijadikan pijakan untuk mengembangkan kemampuan kognitif dan pengetahuannya yang menjadi dasar pembentukan kepercayaan diri. Perempuan yang berpendidikan tinggi lebih cepat beradaptasi dengan kondisi menopause. Keadaan ini disebabkan cara berpikir perempuan berpendidikan tinggi lebih rasional, lebih terbuka dalam menerima informasi, sehingga wawasan dan pengetahuannya lebih luas, dan menghasilkan sikap yang lebih positif dalam menghadapi suatu permasalahan. ${ }^{13}$

Hasil penelitian lain menyatakan adanya hubungan yang positif antara dukungan sosial dengan psychological well-being pada perempuan menopause yang terdiri dari penerimaan diri, hubungan positif dengan orang lain, tujuan hidup, pertumbuhan pribadi, penguasaan terhadap lingkungan, dan otonomi. Hasil penelitian menunjukkan $75 \%$ perempuan menopause memiliki efiksi diri yang baik dan $75 \%$ suami responden memberikan dukungan kuat terhadap istri untuk menghadapi masa menopausenya dan di antaranya sebesar $79,2 \%$ responden yang mempunyai efikasi diri yang baik serta mendapatkan dukungan yang kuat dari suami. Hal ini menunjukkan adanya keterkaitan hubungan, walaupun tidak ditunjukkan dengan hasil yang bermakna secara statistik. Tidak didapatkan teori dan penelitian terdahulu yang mendukung bahwa tidak ada hubungan antara dukungan suami dengan efikasi diri pada perempuan menopause.

Peran dukungan suami memberikan dorongan semangat merupakan hal yang penting dalam proses persuasi verbal untuk meningkatkan efikasi diri istri untuk menjalani masa menopausenya, akan tetapi dibutuhkan keterampilan untuk dapat berhasil. Teori Bandura (1997) menyebutkan persuasi verbal berhubungan dengan kompetensi dan kemampuan diri. Persuasi verbal merupakan keyakinan individu bahwa dirinya dapat memberikan keyakinan terhadap orang lain untuk dapat melakukan kinerja dengan baik pada situasi tertentu. Keyakinan yang berkaitan dengan persuasi verbal adalah sesuatu yang dapat dipelajari. Pengalaman 
masa lalu, terutama yang berkaitan dengan rasa percaya diri, merupakan pengalaman yang dapat meningkatkan persuasi verbal ${ }^{13}$. Individu yang memiliki persuasi verbal tinggi yakin untuk mengarahkan orang lain dan mampu memberikan keyakinan pada orang lain memiliki kemampuan dalam menyelesaikan tugas kerja mereka dengan baik. $^{12}$

Suami yang memiliki persuasi verbal yang tinggi akan dapat mengarahkan pikiran dan tindakan istri dalam menjalankan tugas dan peran sebagai istri dan ibu dalam masa menopause dengan baik, dalam penelitian ini persuasi verbal tidak digali. Diasumsikan bahwa persuasi verbal ini berpengaruh terhadap hasil penelitian.

Sumber lain yang sangat berpengaruh terhadap peningkatan efikasi diri adalah keadaan emosi/fisik yang mengikuti suatu kegiatan akan berpengaruh terhadap efikasi diri di bidang tersebut. Emosi yang kuat, takut, cemas, stres, dapat mengurangi efikasi diri. Namun bisa juga terjadi, peningkatan emosi dalam batas yang tidak berlebihan dapat meningkatkan efikasi diri. Sejalan dengan proses penuaan yang pasti dialami setiap orang, terjadi pula kemunduran fungsi organ-organ tubuh termasuk salah satu organ reproduksi wanita, yaitu ovarium. Terganggunya fungsi ovarium menyebabkan berkurangnya produksi hormon estrogen, dan ini akan menimbulkan beberapa penurunan atau gangguan pada aspek fisik-biologis seksual. Pada sebagian wanita, munculnya gejala atau gangguan fisik sebagai akibat dari berhentinya produksi hormon estrogen, akan berpengaruh pada kondisi psikologis, dan sosialnya. Hal tersebut akan juga memengaruhi efikasi diri pada seseorang yang mengalami menopause. ${ }^{3}$

Menopause seperti halnya menarche pada gadis remaja, perempuan yang mengalami menopause keluhan yang sering dirasakan antara lain: merasa cemas, takut, mudah marah, mudah tersinggung, konsentrasi menurun, gugup, merasa tidak berguna dan tidak berharga, stres, dan bahkan ada yang mengalami depresi. Bagi wanita yang menilai atau menganggap menopause itu sebagai peristiwa yang menakutkan dan berusaha untuk menghindarinya, maka stres pun sulit dihindari. Pada dasarnya rasa takut, cemas, stres yang dialami seseorang, sangat ditentukan oleh bagaimana individu menilai, menginterpretasi, atau mempersepsikan peristiwa yang dialaminya. $^{9}$

Apabila menopause dipandang sebagai hal yang alamiah/sunnatullah bahkan disyukuri atas kenikmatan yang diberikan Allah, maka iapun akan menghadapinya dengan penuh penerimaan dan keikhlasan sehingga berbagai gangguan fisiologis yang dialaminya tidak berdampak pada gangguan psikologis. Hal ini terkait dengan tingkat religiusitas, disebutkan dalam penelitian terdahulu bahwa tingkat religiusitas yang tinggi dapat membantu perempuan menghadapi menopause dan menjalani 
kehidupan paska menopause dengan lancar. ${ }^{10}$

\section{KESIMPULAN}

Sebagian besar (75\%) suami memberikan dukungan kuat terhadap istrinya yang sudah mengalami menopause dan sebagian besar (75\%) istri memiliki efikasi diri yang baik. Dukungan suami secara statistik tidak berhubungan dengan efikasi diri perempuan dalam menjalani masa menopause.

Saran untuk responden diharapkan pasangan suami istri meningkatkan komunikasi secara efektif terkait dengan masalah kesehatan istri pada masa menopause, sehingga dapat meningkatkan dukungan suami yang berdampak pada peningkatan efikasi diri pada perempuan menopause

\section{KEPUSTAKAAN}

1. Badan Pusat Statistik. Statistik Penduduk Lanjut Usia 2014. Jakarta: BPS. 2015.

2. Senba, N., Matsuo, H. Effect of a health education program on climacteric woman. Japan: Kobe university. 2010. https://www.ncbi.nlm.nih.gov/pubmed/2015 1791. diunduh pada 20 Februari 2015.

3. Nuharta, E. Hubungan Pengetahuan dan Sikap Suami tentang Aktifitas Seksual pada Istri Menopause di Kelurahan Simalingkar B, Kec Medan Tungtungan. Skripsi, 2011. http://repository.usu.ac.id/bitstream/123456 789/28058/7pdf. diakses 31 Juli 2012]

4. Kuswardani. Gambaran Peranan Keluarga terhadap Perilaku Hidup Sehat pada Lansia di Wilayah Kerja Puskesmas Darussalam Kecamatan Medan Petisah tahun 2009". Skripsi, 2009. http//: repository.usu.ac.id/bitstream/123456789/1 4741/1/09E02455.pdf. diakses 16 Juli 2015].

5. Effendi, F., Mukhfudli. Keperawatan Kesehatan Komunitas: Teori dan Praktik dalam Keperawatan. Jakarta: Salemba Medika. 2009

6. Millatina. Hubungan antara Dukungan Sosial dengan Psicologycal Well-Being pada wanita menopause (di RS Harapan Bunda Bandung). Jurnal Psikologi Gelombang 2 T.A 2014-2015. 2014.

7. Marga PS. Hubungan Gambaran Diri dengan Tingkat kecemasan lbu Masa Menopause di Kelurahan Lhok Keutapan Tapaktuan. $\quad$ Skripsi.. 2007. http//:repository.usu.ac.id/bitstream/123456 789/14287/1/08E00729.pdf diakses 16 Juli 2015].

8. Bandura, A. (1997). Self-Efficacy The Exercise of Control. New York: W.H. Freeman and Company.

9. Atamimi, Nuryati, and Rasimin Bujang Sanmustari. Ada Apa Dengan Menopause?. Buletin Psikologi 8.1.2015

10. Prasetya, Meithya Rose, Masni Erika Firmiana, and Rochimah Imawati. "Peran Religiusitas Mengatasi Kecemasan Masa Menopause. Seri Humaniora 1.3. 2012: hal 
145157.http//:jurnal.uai.ac.id/index.php/SH /article/download/64/66 diakses 31 Maret 2017

11. Gibson, Ivancevich, donnelly, Konospaske. Organizations Behavior. 2010

12. Kreitner Robert \& Kinicki Angelo.Orgnizational Behavior. Mc Graw-
Hill International. Kevin Hogan \& James. 2010

13. Candra, IW., Trisnadewi N. Kepercayaan diri wanita menopause. Poltekes Denpasar. 2015. http://poltekkesdenpasar.ac.id/files/JURNAL\%20GEMA\% 20KEPERAWATAN/JUNI\%202015/Wayan \%20Candra.pdf. diakses 31 Maret 2017 